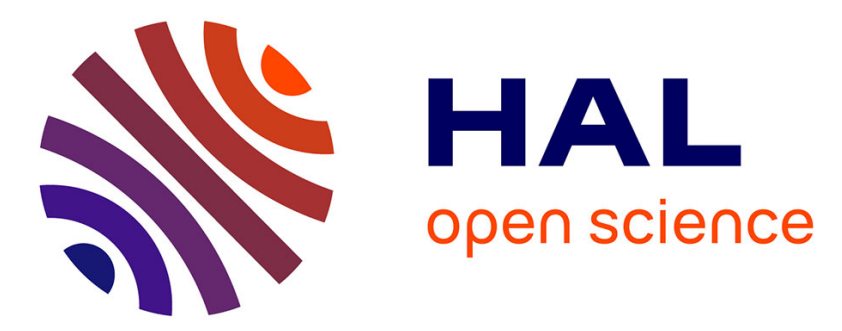

\title{
Predictive factors of unexpected lymphatic drainage pathways in early-stage cervical cancer
}

V. Balaya, P. Mathevet, L. Magaud, H. Bonsang-Kitzis, M. Delomenie, R. Montero Macias, C. Ngô, A.S. Bats, F. Lécuru

\section{- To cite this version:}

V. Balaya, P. Mathevet, L. Magaud, H. Bonsang-Kitzis, M. Delomenie, et al.. Predictive factors of unexpected lymphatic drainage pathways in early-stage cervical cancer. Gynecologic Oncology, 2019, 154, pp.102 - 109. 10.1016/j.ygyno.2019.04.008 . hal-03484903

\section{HAL Id: hal-03484903 \\ https://hal.science/hal-03484903}

Submitted on 20 Dec 2021

HAL is a multi-disciplinary open access archive for the deposit and dissemination of scientific research documents, whether they are published or not. The documents may come from teaching and research institutions in France or abroad, or from public or private research centers.
L'archive ouverte pluridisciplinaire HAL, est destinée au dépôt et à la diffusion de documents scientifiques de niveau recherche, publiés ou non, émanant des établissements d'enseignement et de recherche français ou étrangers, des laboratoires publics ou privés.

\section{(ㅇ)(1) $\$$}

Distributed under a Creative Commons Attribution - NonCommerciall 4.0 International 


\section{Predictive factors of unexpected lymphatic drainage} 2 pathways in early-stage cervical cancer

3

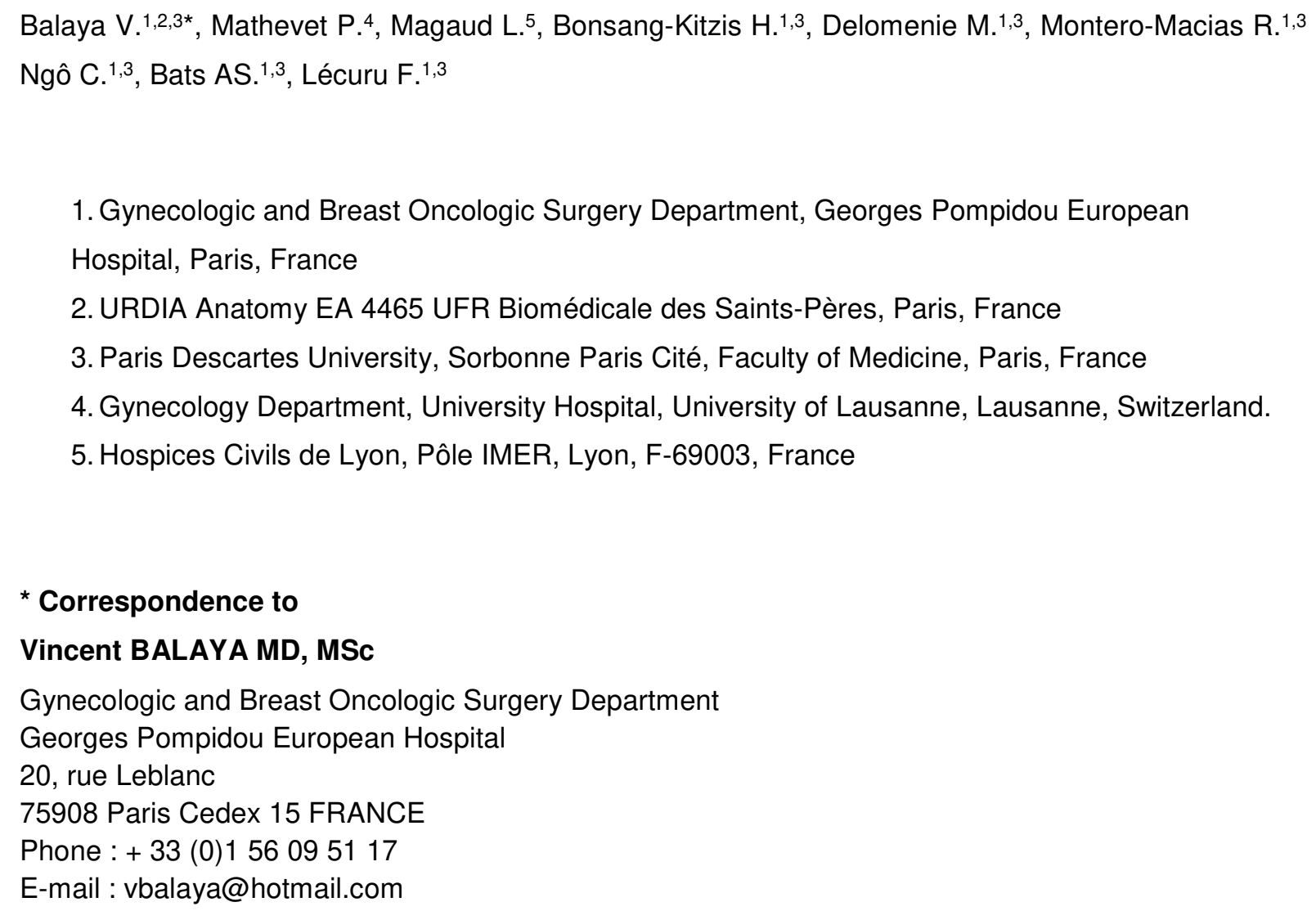

${ }^{*}$ Correspondence to

Vincent BALAYA MD, MSc

Gynecologic and Breast Oncologic Surgery Department

Georges Pompidou European Hospital

20, rue Leblanc 75908 Paris Cedex 15 FRANCE

Phone : + $33(0) 156095117$

E-mail : vbalaya@hotmail.com

Short running title: Predictive factors of unexpected lymphatic drainage pathways of cervical cancer

Words count: 3198 words 


\section{Predictive factors of unexpected lymphatic drainage pathways in early-stage cervical} cancer

Objectives: The purpose of this study was to describe Sentinel lymph nodes (SLN) topography in patients with early-stage cervical cancer and to determine factors associated with atypical lymphatic drainage pathway (LDP).

Methods: We analyzed the data of two prospective multicentric trials on SLN biopsy for cervical cancer (SENTICOL I and II) in women undergoing surgery for early-stage cervical cancer. SLN detection was realized with a combined labeling technique (Patent blue and radioactive tracer). Patients having bilateral SLN detection were included. Univariate and Multivariate analysis were perfomed by patients and by side to assess clinical and pathologic factors that may predict atypical LDP.

Results: Between January 2005 and July 2012, 326 patients with 1104 intraoperative detected SLNs fulfilled the inclusion criteria. The SLNs were mainly located in the interiliac or external iliac area in $83.2 \%$. The other localizations were: $9.2 \%$ in the common iliac area, $3.9 \%$ in the parametrium, $1.6 \%$ in the promontory area, $1.5 \%$ in the paraaortic area and $0.5 \%$ in other areas. Thirty-five patients $(10.7 \%)$ had atypical SLN without SLN in typical area on one or both sides. In multivariate analysis, tumor size $\geq 20 \mathrm{~mm}$ appeared as an independent factor of having at least one exclusive atypical LDP (ORa = $3.9595 \% \mathrm{Cl}=[1.60-9.78], \mathrm{p}=0.003)$. Multiparity decreased significantly the probability of having at least one exclusive atypical LDP $(\mathrm{ORa}=0.1695 \% \mathrm{Cl}=[0.07-0.39], \mathrm{p}<0.0001)$.

Conclusions: Tumor size larger than $20 \mathrm{~mm}$ and nulliparity increase the risk of having exclusive atypical LDP in early-stage cervical cancer.

Key-words: "Cervical cancer", "Sentinel Lymph Node ", "Lymphatic drainage ", «SENTICOL», « Radical hysterectomy »

\section{Introduction}


Cervical cancer is the second most common cancer among women and the third cause of cancer-related deaths in females with approximately 527600 new cases and 265700 deaths each year (1). Lymph node involvement is one of the main major prognosis factors for early-stage cervical cancer $(2,3)$. According to main guidelines $(4,5)$, surgery is the preferred treatment for early-stage cervical cancer (up to FIGO stage IIA1), especially in young patients. Lymph node staging is performed to assess the prognosis and guide the treatment (5). Considering that pelvic lymphadenectomy generates several complications, the sentinel lymph node (SLN) technique has been introduced for 20 years and is increasingly used in cervical cancer. One of the interests of SLN is to highlight the aberrant drainage territories that are not systematically dissected during routine lymphadenectomies (6). Although most of SLNs are located in the interiliac and external ilac area, SLNs have also been described in "unexpected" territories such as sacral, promontory and paraaortic areas (7).

The purpose of the present study was to describe SLNs topography in a large multicentric prospective cohort of patients with early-stage cervical cancer and to determine factors associated with atypical lymphatic drainage pathway (LDP).

\section{Material and methods}

\section{Population study}

We retrospectively analysed the data of two multicentric prospective trials on SLN biopsy for FIGO IA-IIA cervical cancer (SENTICOL I \& II). Design of the both studies have already been described elsewhere $(8,9)$. Patients with early cervical cancer (stage la1 with lymphovascular emboli, IB1 and IIA1) were included consecutively from 7 French gynecological oncology centers for SENTICOL I and 23 French gynecological oncology centers for SENTICOL II.

Briefly, SENTICOL I was a prospective multicenter study assessing the diagnostic value of SLN biopsy in early-stage cervical cancer. One hundred and forty-five patients were enrolled between January 2005 and May 2007 and a systematic pelvic lymphadenectomy was performed after SLN biopsy as well as lymphadenectomy of areas containing one or more SLNs (12). SENTICOL II was a 
prospective randomized multicenter study assessing morbidity and quality of life(13). Two hundred and sixty-seven patients were enrolled and 206 patients with negative SLN at frozen-section examination were randomised between SLN biopsy only (105 patients) or SLN biopsy with additional pelvic lymphadenectomy (101 patients).

In both studies, number and location of SLNs were prospectively recorded in a pre-specified analysis. In this article, patients with early-stage cervical cancer and bilateral SLN detection were included. Bilateral detection was defined as intraoperative detection SLNs in both hemi-pelvises. Patients who had unilateral or no SLNs detected were excluded because LDP could not be assessed intraoperatively. Approval to conduct this study was obtained from the Paris Descartes Ethical Committee (Comité de Protection des Personnes HEGP-Broussais). Patients included in the two studies signed an informed consent stating the use of data for secondary analyses.

\section{Data analysis}

All data were collected from two prospective multicentric databases. Demographic characteristics, surgical history, and clinical data including FIGO stage were extracted. Operative records were reviewed, and data about the type of surgical approach, the type of surgery performed (hysterectomy or trachelectomy) and the operating time were collected.

Sentinel lymph node was detected by a combined labeling technique. The radioactive tracer (colloidal rhenium sulfide labeled with technetium [99mTc] (Nanocis ${ }^{\circledR}$, Cis Bio International, Gif sur Yvette, France)) was injected using a 25-gauge needle into the four cardinal points of the uterine cervix either on the day before surgery (120-MBq; long protocol) or morning of surgery (60-MBq; short protocol). Lymphoscintigraphy was performed routinely, and the results were given to the surgeons before the surgical procedure. At the beginning of the surgical procedure, $2.5 \%$ Patent Blue $(2 \mathrm{~mL}$ diluted in $2 \mathrm{~mL}$ of saline) was injected into the four cardinal points of the cervix.

Intraoperatively, the pelvic and para-aortic nodes were examined before and after opening of the peritoneum, the pararectal, paravesical spaces and exposure of the parametria. SLNs were identified based on the blue color of the lymphatic channels and nodes and on radioactivity detected using an endoscopic gamma detection device. SLNs were selectively removed and the absence of residual in vivo radioactivity was checked. Frozen section analysis was performed either routinely or only on suspected metastasis nodes depending on the center. 
To describe SLN location, we used the area classification suggested by Marnitz et al. (7) : paraaortic (area 1), common iliac (from the bifurcation of the aorta to the bifurcation of the iliac vessels, area 2), external iliac (along the external iliac vessels, area 3), interiliac (nodes medial to the external iliac artery and vein, in the obturator fossa and over the bifurcation of the common iliac artery, area 4), internal iliac (medial to the internal iliac vessels down to the uterine artery bifurcation, including the presacral nodes, area 5), and parametrium (nodes medial to the bifurcation of the uterine artery, area 6 ). Areas 3 and 4 were considered to be located in typical sites whereas the other areas

(areas 1, 2, 5, and 6) were defined as atypical sites. Classic LDP was defined by the presence of SLNs exclusively in typical sites (area 3 and 4). Atypical LDP was defined by the presence of one or more SLNs in atypical sites (area 1,2,5 and 6). Common iliac SLNs were considered to belong to classic LDP if they were associated with SLNs in the interiliac or external iliac area whereas isolated common iliac SLNs (without any SLNs in the interiliac or external iliac area) were considered as belonging to atypical LDP. In the same way, paraaortic SLNs were considered as atypical if they were isolated without any SLNs in the external, interiliac or common iliac area.

SLNs were analysed after hematoxylineosin-saffron (HES) staining of $200-\mu \mathrm{m}$ sections. SLNs negative by HES were examined by immunohistochemistry with anti-cytokeratin AE1-AE3 antibodies. Non-SLNs were cut once and were examined by HES only. Isolated tumor cells (ITCs) were defined as $<0.2 \mathrm{~mm}$, micrometastases as between 0.2 and $2 \mathrm{~mm}$, and macrometastases as $>2 \mathrm{~mm}(10)$.

Pathological data was reviewed (tumor histology, lymphovascular space invasion (LVSI), parametrial status, vaginal margin status, surgical margin status and tumor size).

\section{Statistical analysis}

We performed two analysis: a patient-specific analysis and a side-specific analysis, considering all hemi-pelvises (right and left for each patient). In both analyses, we assessed clinico-pathologic variable associated with the presence or not of exclusive atypical LDP.

Qualitative variables were expressed as $\mathrm{n}(\%)$ and quantitative data as mean [range]. The chisquare test (or Fisher's test if the sample size was too small) was used to compare qualitative variables. The Student's t test was applied to compare quantitative variables.

Variables yielding $p$ values lower than 0.2 by univariate analysis were entered into a multivariate logistic regression model to determine variables independently associated with the presence or not of 
exclusive atypical LDP. Values of $p$ lower than 0.05 were considered as significant.

Data were recorded in an Excel files and statistical analyses were performed using XLStat Biomed software (Addlnsoft V19.4).

\section{Results}

Between January 2005 and July 2012, 412 patients were enrolled in the both studies: 145 in SENTICOL I and 267 in SENTICOL II. Three hundred and twenty-six patients had bilateral SLN detection and were finally included for analysis.

\section{Patient and surgical characteristics}

The median age was 41.5 years [22 - 85 years] and the median Body-Mass Index (BMI) was $22.6 \mathrm{~kg} / \mathrm{m}^{2}\left[14.6-42.2 \mathrm{~kg} / \mathrm{m}^{2}\right]$. Eighty-seven patients (26.7\%) were nulliparous. Most of the patients had FIGO stage IB1 disease (273 patients, $83.7 \%$ ). The majority of patients had squamous cell carcinoma (216 patients, 66.3\%). Thirty-three patients (10.1\%) had only lymph node staging, 4 patients $(1.2 \%)$ a simple trachelectomy, 53 patients (16.3\%) a radical trachelectomy, 10 patients (3.1\%) a simple hysterectomy and $226(69.3 \%)$ a radical hysterectomy. At final pathologic examination, 58 patients $(20.6 \%)$ had a tumor size larger than $20 \mathrm{~mm}$. There were a parametrial spread in 12 patients (3.7\%), a vaginal spread in 12 patients (3.7\%) and positive surgical margin in 14 patients (4.3\%).

\section{SLNs topography and status}

In 326 patients, 1104 SLNs were detected and removed (Table 1). The mean number of removed SLN per patient was $3.8 \pm 1.8$ [2-11] and per hemipelvis was $1.9 \pm 1.3$ [1-9]. SLNs were mainly located in the interiliac or external iliac area (918/1104, 83.2\%). One hundred and two SLNs (9.2\%) were found in common iliac area. Among them, 62 common iliac SLNs were associated with SLNs in the interiliac or external iliac area and therefore were considered as following classical lymphatic drainage pathway whereas 40 common iliac SLNs were isolated and were considered as atypical. In addition to that, 33 SLNs were specifically located in the parametrium (3.9\%), 18 SLNs in 
the promontory area (1.6\%) and 17 SLNs $(1.5 \%)$ were isolated in the paraaortic area. Three SLNs were identified in the right paracervix $0.3 \%$. The topography of 3 SLNs was not precised. The majority of patients had exclusively bilateral classic LDP (246 patients, $75.5 \%)$ whereas 80 patients $(24.5 \%)$ had at least one atypical LDP. In this subgroup of 80 patients, 45 patients (13.8\%) had classic LDP associated with atypical LDP on one or both sides, 32 patients $(9.8 \%)$ had exclusively atypical LDP on one side and 3 patients $(0.9 \%)$ had exclusively atypical LDP on both sides. Among the 652 hemipelvises assessable, 93 hemipelvises (14.3\%) had at least one atypical LDP. Among these 93 hemipelvises, 36 hemipelvises had exclusively atypical LDP. Significantly more SLNs were removed in patients with atypical LDP $(4.5 \pm 2.1$ SLNs vs $3.6 \pm 1.6, p<0.0001)$ and more SLN were removed in hemipelvises with atypical LDP $(2.4 \pm 1.8$ SLNs vs $1.8 \pm 1.1, p<0.0001)$.

In this cohort of 326 patients with 1104 detected SLNs, 68 positive SLNs (6.3\%) were found in 53 patients (16.3\%) (Table 1). Eleven patients had 2 positive SLNs and 2 patients had 3 positives SLNs. Eleven patients had bilateral positive SLNs. Among the 68 positive SLNs, 31 were macrometastasis (45.6\%), 19 were micrometastasis (27.9\%) and 18 were isolated Tumoral cells (ITCs) (26.5\%). Positive SLNs were mainly found in interiliac and external iliac area (60/68, 88.2\%), whereas there were only 3 positive SLNs in the parametrial area $(3 / 68,4.4 \%), 1$ positive SLN in the promontory area $(1 / 68,1.5 \%)$ and 1 positive SLN in the paraaortic area $(1 / 68,1.5 \%)$. Three positive SLNs were located in the common iliac area (3/68, 4.4\%): two were synchronous with a positive SLN in external area and one was isolated. There were no differences between patients without and with SLNs in atypical area in terms of rate of positive SLN and type of positive SLN. If only interiliac and external iliac area were harvested, $83.2 \%$ of SLN and $88.2 \%$ of metastatic SLN were found. In addition, if common ilac, parametrial and promontory areas were also harvested, $97.9 \%$ of SLN and $98.6 \%$ of metastatic SLN were found.

In the subgroup of 80 patients with at least one atypical LDP, 20 SLNs were positive in 15 patients (4.6\%). Among these 20 positive SLNs, 6 positive SLNs were located in atypical areas. Among these 15 patients with positive SLNs, 6 patients had positive SLNs in atypical areas, including 3 patients who had exclusively positive SLNs in atypical area (Table 2).

\section{Patients-specific analysis}

Thirty-five patients (10.7\%) had atypical SLN without SLN in typical area on one or both sides. 
In univariate analysis, the factors which were significantly associated with an exclusive atypical LDP on one or both sides were the parity and the tumor size (Table 3). Nulliparous patients had significantly more exclusive atypical $\operatorname{LDP}(22 / 87,25.3 \%)$ than multiparous patients $(13 / 239,5.4 \%), p$ $<0.0001$. In patients with exclusive atypical LDP, the rate of tumor larger than $20 \mathrm{~mm}$ was significantly higher $(42.3 \%$ vs $18.4 \%, p=0.0004)$. BMI and the type of surgical approach may have an impact but did not reach statistical significance rate. Less exclusive atypical LDP tended to be found in patients with $\mathrm{BMI}>25 \mathrm{~kg} / \mathrm{m}^{2}(5 / 91,5.5 \%)$ than in patients with $\mathrm{BMl} \leq 25 \mathrm{~kg} / \mathrm{m}^{2}(30 / 234,12.8 \%), \mathrm{p}=0.06$. More exclusive atypical LDP seemed to be found in patients operated by minimal invasive approach $(35 / 299,11.7 \%)$ than by open surgery $(0 / 26,0 \%), p=0.06$.

In multivariate analysis, tumor size $\geq 20 \mathrm{~mm}$ appeared as an independent factor of having at least one exclusive atypical LDP $(\mathrm{ORa}=3.9595 \% \mathrm{Cl}=[1.60-9.78], \mathrm{p}=0.003)($ Table 4). Multiparity and $\mathrm{BMI} \geq 25 \mathrm{~kg} / \mathrm{m}^{2}$ decreased significantly the probability of having at least one exclusive atypical $\operatorname{LDP}(\mathrm{ORa}=0.1695 \% \mathrm{Cl}=[0.07-0.39], \mathrm{p}<0.0001$ and $\mathrm{ORa}=0.1795 \% \mathrm{Cl}=[0.03-0.9], \mathrm{p}=0.04$ respectively).

\section{Side-specific analysis}

Among the 652 hemipelvises assessable, exclusive atypical LDP were found in 38 hemipelvises (5.8\%). As previously found in patients-specific analysis, results of the univariate analysis confirmed a significative association between exclusive atypical LDP in each side with nulliparity and tumor size larger than $20 \mathrm{~mm}$ (Table 5). Moreover, less exclusive atypical LDP were significantly retrieved in each hemipelvis in patients with $\mathrm{BMI}>25 \mathrm{~kg} / \mathrm{m}^{2}(5 / 182,2.7 \%)$ than in patients with BMI $\leq 25 \mathrm{~kg} / \mathrm{m}^{2}(33 / 468,7.1 \%), p=0.04$. The same trend with minimal invasive approach was also found without reaching statistical significance rate. Furthermore, parametrial and vaginal invasion tended to be more frequent in hemipelvises with exclusive atypical LDP $(10.7 \%$ vs $3.9 \%, p=0.08$ and $10.7 \%$ vs $4 \%, p=0.09$ respectively)

By multivariate analysis, variable which were independently associated with exclusive atypical LDP in each hemipelvis were parity and tumor size (Table 6). The rate of exclusive atypical LDP by side was decreased in case of multiparity $(\mathrm{ORa}=0.17,95 \% \mathrm{Cl}=[0.07-0.39], \mathrm{p}<0.0001)$. Tumor size larger than $20 \mathrm{~mm}$ increased the probability of exclusive atypical LDP in each hemipelvis $(\mathrm{ORa}=2.52$, $95 \% \mathrm{Cl}=[1.04-6.10], \mathrm{p}=0.04) . \mathrm{BMI}>25 \mathrm{~kg} / \mathrm{m}^{2}$ tended to decrease the incidence of exclusive 


\section{Discussion}

Through this prospective cochort of 326 patients, this study shows that atypical LDP of the uterine cervix concerns up to $24.5 \%$ of patients with early-stage cervical cancer and $8.9 \%$ of positive SLNs are found in atypical area. To our best knowledge, the present study is the first study that precisely assesses predictive factors of atypical LDP. Over the last century, many classifications of uterine lymphatic drainage have been described (11-17). Although the terminology is different according to the authors, all these works support the concept of concomitant atypical lymphatic drainage. More recently, Geppert et al. suggested a uterine lymphatic drainage pathway classification based on SLN mapping in endometrial cancer (11). They injected ICG into the cervix or the uterine fundus. They distinguished the upper paracervical pathway (UPP), the lower paracervical pathway (LPP) and the Infundibulo-pelvic pathway (IPP). The UPP follows the uterine artery and drains to external and/or obturator lymph nodes with a continued course lateral to the common iliac artery and then to the lateral precaval and paraaortic areas. The LPP goes through the sacrouterine ligament to the internal iliac and/or presacral draining nodes before continuing medial to the common iliac artery and then to the medial paraaortic and precaval areas. The IPP has a course along the fallopian tube and upper broad ligament via the Infundibulo-pelvic ligament to its origin.

Ouldamer et al. performed a meta-analysis to determine the frequency of atypical localizations of SLNs in patients with early-stage cervical cancer (18). They analyzed 27 articles which included 1301 patients with 3012 SLNs. They showed that $83.7 \%$ of SLNs were found in classic areas of the pelvis (obturator, external iliac, and internal iliac), $6.6 \%$ in the common iliac area, $4.3 \%$ in the parametrial area, $2.0 \%$ in the paraaortic area, $1.3 \%$ in the presacral area, $0.2 \%$ in the hypogastric area, $0.07 \%$ in the inguinal area, and $0.07 \%$ in the cardinal ligament area. Their results were in accordance with ours. We did not find any SLNs in the inguinal area or in the circumflex iliac area as described by Takeshita et al. (19).

We highlighted that tumor size $\geq 20 \mathrm{~mm}$ have an impact on lymphatic drainage pathway in early-stage cervical cancer. In a retrospective cohort of 350 patients, Dostalek et al. assessed SLN 
biopsy in cervical tumors in 3 subgroups of $<20 \mathrm{~mm}, 20-39 \mathrm{~mm}$ and $\geq 40 \mathrm{~mm}$ tumor size. They shew that bilateral detection rate and false negative rate were similar between the 3 subgroups and concluded that SLN biopsy was reliable in lymph node staging in tumors larger than $20 \mathrm{~mm}$ (20). Lymphatic vessels may be obstructed by cancer cells and it may result in a modification of tumor lymphatic drainage. Furthermore, large tumors can have a central necrotic part that may alter the diffusion of patent blue or/and radiocolloid (21). Tumor cells migration could use other lymphatic drainage pathway than that run to interiliac or external iliac area. This theory may explain that parametrial invasion tended to be more frequent in case of SLNs in atypical area, although this difference did not reach statistical significance.

Surprisingly, we found that multiparity decreased significantly the rate of SLNs identified in atypical area. During pregnancy, uterine vascular and lymphatic network is modified (22). This phenomenon was already described by Cuneo and Marcille in 1901 and they described that in nonpregnant uterus, lymphatics vessels were very thin but during gestation they were hyperplasic (12). Volchek et al. suggested that during pregnancy, endometrial stromal cell decidualization may involve in loss of lymphatics in decidua especially around the spiral arteries but lymphatics vessels were still present and larger in the non-decidualized hypersecretory endometrium (23). Some authors provided evidence about the relation between lymphangiogenesis and lymphatic spread in endometrial cancer $(24,25)$. We feel that all these complex mechanisms associated with lymphatic vessels modification during pregnancy may have an impact on lymphatic drainage pathway in cervical cancer as suggested our results.

According to our results, $\mathrm{BMI} \geq 25 \mathrm{~kg} / \mathrm{m}^{2}$ decreased significantly the rate of SLNs identified in atypical area. Independently of the technique of SLN detection (Fluorescent with Indocyanine green (ICG) or colorimetric with blue dye), Eriksson et al. showed that increasing BMI were significantly associated with a decreasing of bilateral detection of SLNs in patients with uterine cancer but ICG would provide better results than blue dye in the specific population of obese patients (26). Due to the period of both studies SENTICOL I and II, our patients had SLN detection technique with combined labeling technique (blue dye and radiotracer) and not ICG. This point constitutes one of the limitations of our study. Recently, the FILM trial has proven that ICG should become the gold-standard for SLN mapping in uterine cancer (27). In fact, we support the idea that less SLNs were found in atypical area in case of $\mathrm{BMI} \geq 25 \mathrm{~kg} / \mathrm{m}^{2}$ because less SLNs may have been globally found in this group of patients 
due to the fact that visualization of all areas may be suboptimal and the thick layer of retroperitoneal fat may obscure channels.

Another limitation is the retrospective analysis of two databases which were not designed to our specific objectives. However, all data related to SLNs localization were prospectively recorded in a quality-checked database and patients came from multiple expert centers with high surgical skills in SLN biopsy.

Our findings stress the importance of SLN biopsy in the detection of metastatic nodes in aberrant topography that would not be removed during routine pelvic lymphadenectomy. This technique may reduce the false-negative case of lymph node staging and residual disease missing which leads to an undertreatment of patients.

To improve the identification of SLNs in unexpected sites, we suggest opening first the entire retroperitoneal space along the external iliac vessels and to identify the ureter and the obliterated umbilical artery. This approach allows to observe the early drainage from the cervix through the parametrium by following the dye progression in the channels before any node is taken to ensure that the true draining SLN is identified and not missed. Although the false negative rate may be limited by increasing the number of SLNs sampled especially in teams with low experience, not all detected nodes (blue and/or hot SLN) should be taken but only the first draining node in the channel pathway has to be removed and labeled as SLN. This strategy permits to perform a real SLN-mapping and avoids considering as SLNs non-SLNs which correspond in fact to distal migration of tracer beyond the true SLN. However, in case of truly separate channels which may correspond to distinct LDP, more SLNs should be sample. If no SLNs are found in the external iliac, interiliac and common iliac area, dissection of the promontory area and paraaortic area should be performed to avoid missing SLN in atypical topography.

\section{Conclusion}

In patients with early-stage cervical cancer, most of SLNs are found in expected areas but atypical LDP of the uterine cervix concerns up to $24.5 \%$ of these patients. Tumor size larger than 20 $\mathrm{mm}$ and nulliparity increase the risk of having exclusive atypical LDP in early-stage cervical cancer. 
Study concepts:

Study design:

Data acquisition :

Quality control of data and algorithms:

Data analysis and interpretation:

Statistical analysis:

Manuscript preparation:

Manuscript editing:

Manuscript review:
Balaya V., Mathevet P., Bats AS., Lécuru F. Balaya V., Mathevet P., Bats AS., Lécuru F. Mathevet P., Lécuru F., Bats AS., Magaud L., Magaud L., Lécuru F., Mathevet P., Balaya V., Ngô C.

Balaya V., Lécuru F., Mathevet P., Bats AS., Bonsang-Kitzis H., Delomenie M., Montero-Macias R.

Bonsang-Kitzis H., Balaya V.

Balaya V., Lécuru F. Mathevet P.

Balaya V., Lécuru F., Delomenie M., Ngô C., Bats AS. Bonsang-Kitzis H., Montero-Macias R. Lécuru F., Bats AS., Mathevet P.

\section{Conflict of Interest: none}

\section{REFERENCES}

1. Torre LA, Bray F, Siegel RL, Ferlay J, Lortet-Tieulent J, Jemal A. Global cancer statistics, 2012. CA Cancer J Clin. 2015 Mar;65(2):87-108.

2. Benedetti-Panici P, Maneschi F, Scambia G, Greggi S, Cutillo G, D’ Andrea G, et al. Lymphatic spread of cervical cancer: an anatomical and pathological study based on 225 radical hysterectomies with systematic pelvic and aortic lymphadenectomy. Gynecol Oncol. 1996 Jul;62(1):19-24.

3. Ho C-M, Chien T-Y, Huang S-H, Wu C-J, Shih B-Y, Chang S-C. Multivariate analysis of the prognostic factors and outcomes in early cervical cancer patients undergoing radical hysterectomy. Gynecol Oncol. 2004 May;93(2):458-64.

4. Marth C, Landoni F, Mahner S, McCormack M, Gonzalez-Martin A, Colombo N. Cervical cancer: ESMO Clinical Practice Guidelines for diagnosis, treatment and follow-up. Ann Oncol. 2017 Jul 1;28(suppl_4):iv72-iv83.

5. Cibula D, Pötter R, Planchamp F, Avall-Lundqvist E, Fischerova D, Haie Meder C, et al. The European Society of Gynaecological Oncology/European Society for Radiotherapy and Oncology/European Society of Pathology Guidelines for the Management of Patients With Cervical Cancer. Int J Gynecol Cancer. 2018 May;28(4):641.

6. Bats A-S, Mathevet P, Buenerd A, Orliaguet I, Mery E, Zerdoud S, et al. The sentinel node technique detects unexpected drainage pathways and allows nodal ultrastaging in early cervical cancer: insights from the multicenter prospective SENTICOL study. Ann Surg Oncol. 2013 Feb;20(2):413-22.

7. Marnitz S, Köhler C, Bongardt S, Braig U, Hertel H, Schneider A, et al. Topographic distribution of sentinel lymph nodes in patients with cervical cancer. Gynecol Oncol. 2006 Oct;103(1):35-44.

8. Lécuru F, Mathevet P, Querleu D, Leblanc E, Morice P, Daraï E, et al. Bilateral negative sentinel nodes accurately predict absence of lymph node metastasis in early cervical cancer: results of the SENTICOL study. J Clin Oncol Off J Am Soc Clin Oncol. 2011 May 1;29(13):1686-91.

9. Mathevet P, Lécuru F, Magaud L, Bouttitie F. Sentinel lymph node biopsy for early cervical cancer: Results of a randomized prospective, multicenter study (Senticol 2) comparing adding pelvic lymph node dissection vs sentinel node biopsy only. Gynecol Oncol. 2017 Jun;145, Supplement 1:2-3.

10. Hermanek P, Hutter RV, Sobin LH, Wittekind C. International Union Against Cancer. Classification of 
isolated tumor cells and micrometastasis. Cancer. 1999 Dec 15;86(12):2668-73.

11. Geppert B, Lönnerfors C, Bollino M, Arechvo A, Persson J. A study on uterine lymphatic anatomy for standardization of pelvic sentinel lymph node detection in endometrial cancer. Gynecol Oncol. 1901 ; 3: 653-663.

13. Leveuf J, Godard H. Les lymphatiques de l'uterus. Rev Chir. 61:219-48.

14. Lécuru F, Neji K, Robin F, Darles C, Bièvre P de, Taurelle R. Drainage lymphatique de l'utérus. J Gynécologie Obstétrique Biol Reprod. 2008 Aug 3;26(4):418.

15. Ercoli A, Delmas V, Iannone V, Fagotti A, Fanfani F, Corrado G, et al. The lymphatic drainage of the uterine cervix in adult fresh cadavers: anatomy and surgical implications. Eur J Surg Oncol J Eur Soc Surg Oncol Br Assoc Surg Oncol. 2010 Mar;36(3):298-303.

16. Bonneau C, Cortez A, Lis R, Mirshahi M, Fauconnier A, Ballester M, et al. Lymphatic and nerve distribution throughout the parametrium. Gynecol Oncol. 2013 Dec;131(3):708-13.

17. Kraima AC, Derks M, Smit NN, Van Munsteren JC, Van der Velden J, Kenter GG, et al. Lymphatic drainage pathways from the cervix uteri: implications for radical hysterectomy? Gynecol Oncol. 2014 Jan;132(1):107-13.

18. Ouldamer L, Marret H, Acker O, Barillot I, Body G. Unusual localizations of sentinel lymph nodes in early stage cervical cancer: a review. Surg Oncol. 2012 Sep;21(3):e153-157.

19. Takeshita S, Todo Y, Okamoto K, Sudo S, Yamashiro K, Kato H. Incidence of metastasis in circumflex iliac nodes distal to the external iliac nodes in cervical cancer. J Gynecol Oncol. 2016 Jul;27(4):e42.

20. Dostálek L, Zikan M, Fischerova D, Kocian R, Germanova A, Frühauf F, et al. SLN biopsy in cervical cancer patients with tumors larger than $2 \mathrm{~cm}$ and 4cm. Gynecol Oncol. 2018;148(3):456-60.

21. Red-Horse K. Lymphatic vessel dynamics in the uterine wall. Placenta. 2008 Mar;29 Suppl A:S55-59.

22. Volchek M, Girling JE, Lash GE, Cann L, Kumar B, Robson SC, et al. Lymphatics in the human endometrium disappear during decidualization. Hum Reprod Oxf Engl. 2010 Oct;25(10):2455-64.

23. Koukourakis MI, Giatromanolaki A, Sivridis E, Simopoulos C, Gatter KC, Harris AL, et al. LYVE-1 immunohistochemical assessment of lymphangiogenesis in endometrial and lung cancer. J Clin Pathol. 2005 Feb;58(2):202-6.

24. He Y, Rajantie I, Ilmonen M, Makinen T, Karkkainen MJ, Haiko P, et al. Preexisting lymphatic endothelium but not endothelial progenitor cells are essential for tumor lymphangiogenesis and lymphatic metastasis. Cancer Res. 2004 Jun 1;64(11):3737-40.

25. Eriksson AGZ, Montovano M, Beavis A, Soslow RA, Zhou Q, Abu-Rustum NR, et al. Impact of Obesity on Sentinel Lymph Node Mapping in Patients with Newly Diagnosed Uterine Cancer Undergoing Robotic Surgery. Ann Surg Oncol. 2016 Aug;23(8):2522-8.

26. Frumovitz M, Plante M, Lee PS, Sandadi S, Lilja JF, Escobar PF, et al. The FILM Trial: A randomized phase III multicenter study assessing near infrared fluorescence in the identification of sentinel lymph nodes (SLN). Gynecol Oncol. 2018 Jun 1;149:7. 


\begin{tabular}{|c|c|c|c|c|c|c|c|c|c|c|c|c|}
\hline \multirow{3}{*}{ Predictive variable } & \multirow{2}{*}{\multicolumn{2}{|c|}{$\begin{array}{c}\text { Total Patients } \\
\mathrm{N}=326 \\
\text { Total SLN } \\
\mathrm{N}=1104\end{array}$}} & \multicolumn{5}{|c|}{ PATIENT-SPECIFIC } & \multicolumn{5}{|c|}{ SIDE-SPECIFIC } \\
\hline & & & \multicolumn{2}{|c|}{$\begin{array}{l}\text { Patients with no SLNs in } \\
\text { atypical areas } \\
N=246\end{array}$} & \multicolumn{2}{|c|}{$\begin{array}{l}\text { Patients with at least one } \\
\text { SLN in atypical areas } \\
\qquad \mathbf{N}=80\end{array}$} & \multirow[t]{2}{*}{$\boldsymbol{P}$} & \multicolumn{2}{|c|}{$\begin{array}{l}\text { Side with no SLNs in } \\
\text { atypical areas } \\
N=559\end{array}$} & \multicolumn{2}{|c|}{$\begin{array}{l}\text { Side with at least one SLN } \\
\text { in atypical areas } \\
\qquad=93\end{array}$} & \multirow[t]{2}{*}{$\boldsymbol{P}$} \\
\hline & $\underset{\text { Mean }}{n} \pm$ SD & $\begin{array}{c}{[\%]} \\
\text { [range] }\end{array}$ & $\underset{\text { Mean }}{n} \pm$ SD & $\begin{array}{c}\text { [\%] } \\
\text { [range] }\end{array}$ & $\begin{array}{c}n \\
\text { Mean } \pm \text { SD }\end{array}$ & $\begin{array}{c}{[\%]} \\
\text { [range] }\end{array}$ & & $\underset{\text { Mean }}{n} \pm$ SD & $\begin{array}{c}\text { [\%] } \\
\text { [range] }\end{array}$ & $\underset{\text { Mean }}{n} \pm$ SD & $\begin{array}{c}{[\%]} \\
\text { [range] }\end{array}$ & \\
\hline \multicolumn{13}{|l|}{ Type of SLN } \\
\hline Blue and Hot & 650 & 58.9 & 471 & 62,0 & 179 & 53,4 & \multirow{4}{*}{0.03} & 539 & 62,2 & 111 & 50,7 & \multirow{4}{*}{0.007} \\
\hline Hot & 265 & 24 & 170 & 22,4 & 95 & 28,4 & & 190 & 21,9 & 65 & 29,7 & \\
\hline Blue & 180 & 16.3 & 119 & 15,7 & 61 & 18,2 & & 137 & 15,8 & 43 & 19,6 & \\
\hline Not specified & 9 & 0.8 & & & & & & & & & & \\
\hline \multicolumn{13}{|l|}{ Topography of SLN } \\
\hline Interiliac/External iliac area & 918 & 83.2 & 724 & 94,3 & 194 & 57,7 & \multirow{7}{*}{$<0.0001$} & 828 & 93,6 & 90 & 41,1 & \multirow{7}{*}{$<0.0001$} \\
\hline Common iliac area & 102 & 9.2 & 44 & 5,7 & 58 & 17,3 & & 57 & 6,4 & 45 & 20,5 & \\
\hline Parametrial area & 43 & 3.9 & 0 & 0,0 & 43 & 12,8 & & 0 & 0,0 & 43 & 19,6 & \\
\hline Promontory area & 18 & 1.6 & 0 & 0,0 & 18 & 5,4 & & 0 & 0,0 & 18 & 8,2 & \\
\hline Paraaortic area & 17 & 1.5 & 0 & 0,0 & 17 & 5,1 & & 0 & 0,0 & 17 & 7,8 & \\
\hline Other & 6 & 0.3 & 0 & 0,0 & 6 & 1,8 & & 0 & 0,0 & 6 & 2,7 & \\
\hline Total & 1104 & 100 & 768 & 100 & 336 & 100 & & & & & & \\
\hline \multicolumn{13}{|l|}{ Number of removed nodes } \\
\hline Number of SLN per patient & $3.8 \pm 1.8$ & {$[2-11]$} & $3.6 \pm 1.6$ & {$[2-11]$} & $4.5 \pm 2.1$ & {$[2-10]$} & \multirow[t]{2}{*}{$<0.0001$} & - & - & - & - & - \\
\hline Number of SLN per hemipelvis & $1.9 \pm 1.3$ & {$[1-9]$} & - & - & - & - & & $1.8 \pm 1.1$ & {$[1-9]$} & $2.4 \pm 1.8$ & {$[1-8]$} & $<0.0001$ \\
\hline \multicolumn{13}{|l|}{ Node status } \\
\hline Patients with positive SLN & & & & & & & & & & & & \\
\hline Yes & 53 & 16.3 & 38 & 15,4 & 15 & 18,8 & & - & - & - & - & \\
\hline No & 273 & 83.7 & 208 & 84,6 & 65 & 81,3 & 0.49 & - & - & - & - & - \\
\hline Side with positive SLN & & & & & & & & & & & & \\
\hline Yes & 64 & 9,8 & - & - & - & - & & 54 & 9,7 & 10 & 10,8 & 0.74 \\
\hline No & 588 & 90,2 & - & - & - & - & - & 505 & 90,3 & 83 & 89,2 & 0.14 \\
\hline Number positive SLN & & & & & & & & & & & & \\
\hline Yes & 68 & 6.2 & 48 & 6,3 & 20 & 6,0 & & 57 & 6,4 & 11 & 5,0 & \\
\hline No & 1036 & 93.8 & 720 & 93,8 & 316 & 94,0 & 0.85 & 828 & 93,6 & 208 & 95,0 & 0.43 \\
\hline Type of positive SLN & & & & & & & & & & & & \\
\hline Macrometastasis & $31 / 68$ & 45.6 & $20 / 48$ & 41,7 & $11 / 20$ & 55,0 & & $23 / 57$ & 40,4 & $8 / 11$ & 72,7 & \\
\hline Micrometastasis & $19 / 68$ & 27.9 & $16 / 48$ & 33,3 & $3 / 20$ & 15,0 & 0.32 & $17 / 57$ & 29,8 & $2 / 11$ & 18,2 & 0.17 \\
\hline ITC & $18 / 68$ & 26.5 & $12 / 48$ & 25,0 & $6 / 20$ & 30,0 & & $17 / 57$ & 29,8 & $1 / 11$ & 9,1 & \\
\hline Topography of positive SLN & & & & & & & & & & & & \\
\hline Topography of overall metastasis & & & & & & & & & & & & \\
\hline Interiliac/External iliac area & $60 / 68$ & 88.2 & $46 / 48$ & 95,8 & $14 / 20$ & 70,0 & & $55 / 57$ & 96,5 & $5 / 11$ & 45,5 & \\
\hline Common iliac area & $3 / 68$ & 4.4 & $2 / 48$ & 4,2 & $1 / 20$ & 5,0 & & 2/57 & 3,5 & $1 / 11$ & 9,1 & \\
\hline Parametrial area & $3 / 68$ & 4.4 & $0 / 48$ & 0,0 & $3 / 20$ & 15,0 & 0.005 & 0/57 & 0,0 & $3 / 11$ & 27,3 & $<0.0001$ \\
\hline Promonotory area & $1 / 68$ & 1.5 & $0 / 48$ & 0,0 & $1 / 20$ & 5,0 & & $0 / 57$ & 0,0 & $1 / 11$ & 9,1 & \\
\hline Paraaortic area & $1 / 68$ & 1.5 & $0 / 48$ & 0,0 & $1 / 20$ & 5,0 & & 0/57 & 0,0 & $1 / 11$ & 9,1 & \\
\hline Topography of macrometastasis & & & & & & & & & & & & \\
\hline Interiliac/External iliac area & $26 / 31$ & 83.9 & $20 / 20$ & 100 & $6 / 11$ & 54,5 & & $23 / 23$ & 100,0 & $3 / 8$ & 37,5 & \\
\hline Parametrial area & $3 / 31$ & 9.7 & 0/20 & 0 & $3 / 11$ & 27,3 & & $0 / 23$ & 0,0 & $1 / 8$ & 12,5 & \\
\hline Promonotory area & $1 / 31$ & 3.2 & 0/20 & 0 & $1 / 11$ & 9,1 & 0.003 & $0 / 23$ & 0,0 & $1 / 8$ & 12,5 & $<0.001$ \\
\hline Paraaortic area & $1 / 31$ & 3.2 & $0 / 20$ & 0 & $1 / 11$ & 9,1 & & $23 / 23$ & 100,0 & $3 / 8$ & 37,5 & \\
\hline Topography of micrometastasis & & & & & & & & & & & & \\
\hline Interiliac/External iliac area & $17 / 19$ & 89.5 & $14 / 16$ & 87,5 & $3 / 3$ & 100 & & $15 / 17$ & 88,2 & $2 / 2$ & 100,0 & \\
\hline Common iliac area & $2 / 19$ & 10.5 & $2 / 16$ & 12,5 & $0 / 3$ & 0 & 0.71 & $2 / 17$ & 11,8 & $0 / 2$ & 0,0 & 0.99 \\
\hline
\end{tabular}


Interiliac/External iliac area

$17 / 18$

94.4

$12 / 12$

100

$5 / 6$

83.3

0.72

$17 / 17$

100

$0 / 1$

$1 / 1$

Table 1. SLN status and topography 


\begin{tabular}{|c|c|c|c|c|c|c|c|c|c|c|}
\hline Patient & $\begin{array}{c}\text { Age } \\
\text { (years) }\end{array}$ & $\begin{array}{c}\text { BMI } \\
(\mathrm{kg} / \mathrm{m} 2)\end{array}$ & Parity & FIGO stage & Histologic type & $\begin{array}{l}\text { Tumor } \\
\text { size }\end{array}$ & $\begin{array}{l}\text { Number } \\
\text { of total } \\
\text { positive } \\
\text { SLN }\end{array}$ & $\begin{array}{l}\text { Localisation of } \\
\text { positive SLN in } \\
\text { atypical area }\end{array}$ & $\begin{array}{c}\text { Type of } \\
\text { positive SLN in } \\
\text { atypical area }\end{array}$ & $\begin{array}{l}\text { Positive SLN } \\
\text { in interiliac } \\
\text { or external } \\
\text { area } \\
\text { associated }\end{array}$ \\
\hline 1 & 39 & 24.0 & Nulliparous & IIB & $\begin{array}{l}\text { Squamous cell } \\
\text { carcinoma }\end{array}$ & 50 & 1 & Common iliac area & ITCs & No \\
\hline 2 & 38 & 25.0 & Nulliparous & IB1 & $\begin{array}{l}\text { Squamous cell } \\
\text { carcinoma }\end{array}$ & 4 & 1 & Parametrial area & Macrometastasis & No \\
\hline 3 & 30 & 28.1 & Nulliparous & IB1 & Adenocarcinoma & 20 & 2 & Parametrial area & Macrometastasis & Yes \\
\hline 4 & 49 & 38.8 & Multiparous & IIB & $\begin{array}{l}\text { Squamous cell } \\
\text { carcinoma }\end{array}$ & 21 & 3 & Parametrial area & Macrometastasis & Yes \\
\hline 5 & 36 & 31.1 & Multiparous & IB1 & Adenocarcinoma & 26 & 1 & Promontory area & Macrometastasis & No \\
\hline 6 & 54 & 17.0 & Multiparous & IB1 & $\begin{array}{l}\text { Squamous cell } \\
\text { carcinoma }\end{array}$ & 26 & 2 & Paraaortic area & Macrometastasis & Yes \\
\hline
\end{tabular}

Table 2. Description of patients with metastatic SLN in atypical localisation 
Table 3. Univariate analysis of predictive factors of having at least one exclusive atypical LDP per patients

\begin{tabular}{|c|c|c|c|c|c|c|c|}
\hline \multirow[t]{2}{*}{ Predictive variable } & \multicolumn{2}{|c|}{$\begin{array}{l}\text { Total population } \\
\qquad \mathrm{N}=326\end{array}$} & \multicolumn{2}{|c|}{$\begin{array}{c}\text { Patients with } \\
\text { bilateral classic LDP } \\
\text { N = 291 }\end{array}$} & \multicolumn{2}{|c|}{$\begin{array}{l}\text { Patients with at least one } \\
\text { exclusive atypical LDP } \\
\qquad N=35\end{array}$} & \multirow[t]{2}{*}{$P$} \\
\hline & $\begin{array}{c}n \\
\text { Mean } \pm \text { SD }\end{array}$ & $\begin{array}{c}\text { [\%] } \\
\text { [range] }\end{array}$ & $\begin{array}{c}n \\
\text { Mean } \pm \text { SD }\end{array}$ & $\begin{array}{c}\text { [\%] } \\
\text { [range] }\end{array}$ & $\begin{array}{c}n \\
\text { Mean } \pm \text { SD }\end{array}$ & $\begin{array}{c}\text { [\%] } \\
\text { [range] }\end{array}$ & \\
\hline \multicolumn{8}{|l|}{ Age [years] } \\
\hline Mean & $43.6 \pm 11.8$ & {$[22-85]$} & $43.6 \pm 11.6$ & {$[23-85]$} & $43.7 \pm 13.7$ & [22-79] & 0.96 \\
\hline$<50$ & 248 & 76.1 & 222 & 76.3 & 26 & 74.3 & \\
\hline $50-70$ & 68 & 20.9 & 61 & 21.0 & 7 & 20.0 & 0.63 \\
\hline$\geq 70$ & 10 & 3.1 & 8 & 2.7 & 2 & 5.7 & \\
\hline \multicolumn{8}{|l|}{ BMI $\left[\mathrm{kg} / \mathrm{m}^{2}\right]$} \\
\hline Mean & $23.6 \pm 5.0$ & {$[14.6-42.2]$} & $23.8 \pm 5.1$ & [14.6 - 42.2] & $22.4 \pm 3.5$ & {$[16.0-31.1]$} & 0.11 \\
\hline$\leq 25$ & $234 / 325$ & 72.0 & $204 / 290$ & 70.3 & 30 & 85.7 & \\
\hline$>25$ & $91 / 325$ & 28.0 & $86 / 290$ & 29.7 & 5 & 14.3 & 0.06 \\
\hline \multicolumn{8}{|l|}{ Parity } \\
\hline 0 & 87 & 26.7 & 65 & 22.3 & 22 & 62.9 & \\
\hline$\geq 1$ & 239 & 73.3 & 226 & 77.7 & 13 & 37.1 & $<0.0007$ \\
\hline \multicolumn{8}{|l|}{ Menopausal status } \\
\hline Yes & 88 & 27.0 & 79 & 27.1 & 9 & 25.7 & \\
\hline No & 238 & 73.0 & 212 & 72.9 & 26 & 74.3 & 0.80 \\
\hline \multicolumn{8}{|l|}{ History of previous pelvic surgery } \\
\hline 0 & 180 & 55.2 & 158 & 54.3 & 22 & 62.9 & O 34 \\
\hline$\geq 1$ & 146 & 44.8 & 133 & 45.7 & 13 & 37.1 & 0.34 \\
\hline \multicolumn{8}{|l|}{ FIGO stage } \\
\hline IA1 with emboli - IA2 & $35 / 314$ & 11.1 & $32 / 282$ & 11.3 & $3 / 32$ & 9.4 & \\
\hline IB1 & $273 / 314$ & 86.9 & $244 / 282$ & 86.5 & 29/32 & 90.6 & 0.66 \\
\hline IIA & $6 / 314$ & 1.9 & 6/282 & 2.1 & $0 / 32$ & 0.0 & \\
\hline \multicolumn{8}{|l|}{ Histology } \\
\hline Squamous cell carcinoma & $216 / 310$ & 69.7 & $194 / 278$ & 69.8 & $22 / 32$ & 68.8 & \\
\hline Adenocarcinoma & $87 / 310$ & 28.1 & $77 / 278$ & 27.7 & $10 / 32$ & 31.3 & 0.62 \\
\hline Other type & $7 / 310$ & 2.3 & $7 / 278$ & 2.5 & $0 / 32$ & 0.0 & \\
\hline \multicolumn{8}{|l|}{ Preoperative LEEP } \\
\hline Yes & $193 / 310$ & 62.3 & $175 / 278$ & 62.9 & $18 / 32$ & 56.3 & 0.46 \\
\hline No & $117 / 310$ & 37.7 & $103 / 278$ & 37.1 & $14 / 32$ & 43.8 & 0.46 \\
\hline Preoperative brachytherapy & & & & & & & \\
\hline
\end{tabular}




\begin{tabular}{|c|c|c|c|c|c|c|c|}
\hline $\begin{array}{l}\text { Yes } \\
\text { No }\end{array}$ & $\begin{array}{c}51 / 263 \\
212 / 263\end{array}$ & $\begin{array}{l}19.4 \\
80.6\end{array}$ & $\begin{array}{c}46 / 238 \\
192 / 238\end{array}$ & $\begin{array}{l}19.3 \\
80.7\end{array}$ & $\begin{array}{c}5 / 25 \\
20 / 25\end{array}$ & $\begin{array}{l}20.0 \\
80.0\end{array}$ & 0.94 \\
\hline \multicolumn{8}{|l|}{ Type of surgical approach } \\
\hline Minimal Invasive Surgery & 299/325 & 92.0 & $264 / 290$ & 91.0 & 35 & 100.0 & \multirow{2}{*}{0.06} \\
\hline Laparotomy & $26 / 325$ & 8.0 & $26 / 290$ & 9.0 & 0 & 0.0 & \\
\hline \multicolumn{8}{|l|}{ Node status } \\
\hline \multicolumn{8}{|l|}{ Patients with positive SLN } \\
\hline Yes & 53 & 16.3 & 47 & 16.2 & 6 & 17.1 & \multirow{2}{*}{0.88} \\
\hline No & 273 & 83.7 & 244 & 83.8 & 29 & 82.9 & \\
\hline \multicolumn{8}{|l|}{ Final pathologic exam } \\
\hline \multicolumn{8}{|l|}{ Tumor size } \\
\hline$<20 \mathrm{~mm}$ & $223 / 281$ & 79.4 & 208/255 & 81.6 & $15 / 26$ & 57.7 & \multirow{3}{*}{0.0004} \\
\hline$\geq 20 \mathrm{~mm}$ & $58 / 281$ & 20.6 & $47 / 255$ & 18.4 & $11 / 26$ & 42.3 & \\
\hline \multicolumn{7}{|l|}{ LVSI } & \\
\hline Yes & $87 / 292$ & 29.8 & 79/265 & 29.8 & $8 / 27$ & 29.6 & \multirow{3}{*}{0.98} \\
\hline No & 205/292 & 70.2 & $186 / 265$ & 70.2 & $19 / 27$ & 70.4 & \\
\hline \multicolumn{7}{|l|}{ Parametrial invasion } & \\
\hline Yes & $12 / 283$ & 4.2 & $10 / 257$ & 3.9 & $2 / 26$ & 7.7 & \multirow{2}{*}{0.36} \\
\hline No & $271 / 283$ & 95.8 & $247 / 257$ & 96.1 & $24 / 26$ & 92.3 & \\
\hline \multicolumn{8}{|l|}{ Vaginal invasion } \\
\hline Yes & $12 / 276$ & 4.3 & $10 / 250$ & 4.0 & $2 / 26$ & 7.7 & \multirow{2}{*}{0.38} \\
\hline No & $264 / 276$ & 95.7 & $240 / 250$ & 96.0 & $24 / 26$ & 92.3 & \\
\hline \multicolumn{8}{|l|}{ Positive margin } \\
\hline Yes & $14 / 282$ & 5.0 & $11 / 256$ & 4.3 & $3 / 26$ & 11.5 & \multirow{2}{*}{0.1} \\
\hline No & $268 / 282$ & 95.0 & $245 / 256$ & 95.7 & $23 / 26$ & 88.5 & \\
\hline
\end{tabular}


Table 4. Multivariate analysis of predictive factors of having at least one SLN in atypical area per patients

\begin{tabular}{|c|c|c|c|}
\hline Variable & ORa & IC $95 \%$ & $p$ \\
\hline \multicolumn{4}{|l|}{ BMI $\left[\mathrm{kg} / \mathrm{m}^{2}\right]$} \\
\hline$\leq 25$ & 1 & & \\
\hline$>25$ & 0.17 & $0.03-0.9$ & 0.04 \\
\hline \multicolumn{4}{|l|}{ Parity } \\
\hline 0 & 1 & & \\
\hline$\geq 1$ & 0.16 & $0.07-0.39$ & $<0.0001$ \\
\hline \multicolumn{4}{|l|}{ Type of surgical approach } \\
\hline Minimal Invasive Surgery & 1 & & \\
\hline Laparotomy & 0.41 & $0.02-7.87$ & 0.56 \\
\hline \multicolumn{4}{|l|}{ Tumor size } \\
\hline$<20 \mathrm{~mm}$ & 1 & & \\
\hline$\geq 20 \mathrm{~mm}$ & 3.95 & $1.60-9.78$ & 0.003 \\
\hline
\end{tabular}


Table 5. Univariate analysis of predictive factors of having at least one atypical SLNs per side

\begin{tabular}{|c|c|c|c|c|c|c|c|}
\hline \multirow[t]{2}{*}{ Predictive variable } & \multicolumn{2}{|c|}{$\begin{array}{c}\text { Total side } \\
\mathrm{N}=652\end{array}$} & \multicolumn{2}{|c|}{$\begin{array}{c}\text { Side with } \\
\text { classic LDP } \\
N=614\end{array}$} & \multicolumn{2}{|c|}{$\begin{array}{c}\text { Side with } \\
\text { exclusive atypical LDP } \\
\mathbf{N}=38\end{array}$} & \multirow[t]{2}{*}{$\boldsymbol{P}$} \\
\hline & $\begin{array}{c}n \\
\text { Mean } \pm \text { SD }\end{array}$ & $\begin{array}{c}\text { [\%] } \\
\text { [range] }\end{array}$ & $\underset{\text { Mean } \pm \text { SD }}{n}$ & $\begin{array}{c}\text { [\%] } \\
\text { [range] }\end{array}$ & $\begin{array}{c}n \\
\text { Mean } \pm \text { SD }\end{array}$ & $\begin{array}{c}\text { [\%] } \\
\text { [range] }\end{array}$ & \\
\hline \multicolumn{8}{|l|}{ Age [years] } \\
\hline Mean & $43.6 \pm 11.8$ & {$[22-85]$} & $43.6 \pm 11.7$ & {$[22-85]$} & $43.6 \pm 13.3$ & [22-79] & 0.98 \\
\hline$<50$ & 496 & 76.1 & 468 & 76.2 & 28 & 73.7 & \\
\hline $50-70$ & 136 & 20.9 & 128 & 20.8 & 8 & 21.1 & 0.72 \\
\hline$\geq 70$ & 20 & 3.1 & 18 & 2.9 & 2 & 5.3 & \\
\hline \multicolumn{8}{|l|}{ BMI $\left[\mathrm{kg} / \mathrm{m}^{2}\right]$} \\
\hline Mean & $23.6 \pm 5.0$ & {$[14.6-42.2]$} & $23.7 \pm 5.0$ & [14.6 - 42.2] & $23.0 \pm 4.9$ & {$[16-31.1]$} & 0.11 \\
\hline$\leq 25$ & $468 / 650$ & 72 & $435 / 612$ & 71.1 & 33 & 86.8 & \\
\hline$>25$ & $182 / 650$ & 28 & $177 / 612$ & 28.9 & 5 & 13.2 & 0.04 \\
\hline \multicolumn{8}{|l|}{ Parity } \\
\hline 0 & 174 & 26.7 & 150 & 24.4 & 24 & 63.2 & \multirow{2}{*}{$<0.0001$} \\
\hline$\geq 1$ & 478 & 73.3 & 464 & 75.6 & 14 & 36.8 & \\
\hline \multicolumn{8}{|l|}{ Menopausal status } \\
\hline Yes & 176 & 27.0 & 166 & 27.0 & 10 & 26.3 & \multirow{2}{*}{0.92} \\
\hline No & 476 & 73.0 & 448 & 73.0 & 28 & 73.7 & \\
\hline \multicolumn{8}{|l|}{ History of previous pelvic surgery } \\
\hline 0 & 360 & 55.2 & 336 & 54.7 & 24 & 63.2 & \multirow{2}{*}{0.31} \\
\hline$\geq 1$ & 292 & 44.8 & 278 & 45.3 & 14 & 36.8 & \\
\hline \multicolumn{8}{|l|}{ FIGO stage } \\
\hline IA1 with emboli - IA2 & $70 / 628$ & 11.1 & $67 / 593$ & 11.3 & $3 / 35$ & 8.6 & \multirow{3}{*}{0.60} \\
\hline IB1 & $546 / 628$ & 86.9 & $514 / 593$ & 86.7 & $32 / 35$ & 91.4 & \\
\hline IIA & $12 / 628$ & 1.9 & $12 / 593$ & 2.0 & $0 / 35$ & 0.0 & \\
\hline \multicolumn{8}{|l|}{ Histology } \\
\hline Squamous cell carcinoma & $432 / 620$ & 69.7 & $407 / 585$ & 69.6 & $25 / 35$ & 71.4 & \multirow{3}{*}{0.65} \\
\hline Adenocarcinoma & $174 / 620$ & 28.1 & $164 / 585$ & 28.0 & $10 / 35$ & 28.6 & \\
\hline Other type & $14 / 620$ & 2.3 & $14 / 585$ & 2.4 & $0 / 35$ & 0.0 & \\
\hline \multicolumn{8}{|l|}{ Preoperative LEEP } \\
\hline Yes & $386 / 620$ & 62.3 & $365 / 585$ & 62.4 & $21 / 35$ & 60.0 & \multirow{2}{*}{0.78} \\
\hline No & $234 / 620$ & 37.7 & $220 / 585$ & 37.6 & $14 / 35$ & 40.0 & \\
\hline
\end{tabular}




\begin{tabular}{|c|c|c|c|c|c|c|c|}
\hline \multicolumn{8}{|l|}{ Preoperative brachytherapy } \\
\hline Yes & $134 / 500$ & 26.8 & $128 / 476$ & 26.9 & $6 / 24$ & 25.0 & \multirow{2}{*}{0.84} \\
\hline No & $366 / 500$ & 73.2 & $348 / 476$ & 73.1 & $18 / 24$ & 75.0 & \\
\hline \multicolumn{8}{|l|}{ Type of surgical approach } \\
\hline Minimal Invasive Surgery & $598 / 650$ & 92.0 & $560 / 612$ & 91.5 & 38 & 100.0 & \multirow{2}{*}{0.06} \\
\hline Laparotomy & $52 / 650$ & 8.0 & $52 / 612$ & 8.5 & 0 & 0.0 & \\
\hline \multicolumn{8}{|l|}{ Node status } \\
\hline Patients with positive SLN & & & & & & & \multirow{3}{*}{0.88} \\
\hline Yes & 64 & 9.8 & 60 & 9.8 & 4 & 10.5 & \\
\hline No & 588 & 90.2 & 554 & 90.2 & 34 & 89.5 & \\
\hline \multicolumn{8}{|l|}{ Final pathologic exam } \\
\hline \multicolumn{8}{|l|}{ Tumor size } \\
\hline$<20 \mathrm{~mm}$ & $448 / 561$ & 79.9 & 432 & 81.4 & $16 / 30$ & 53.3 & \multirow{2}{*}{0.0002} \\
\hline$\geq 20 \mathrm{~mm}$ & $113 / 561$ & 20.1 & 99 & 18.6 & $14 / 30$ & 46.7 & \\
\hline \multicolumn{8}{|l|}{ LVSI } \\
\hline Yes & $174 / 584$ & 29.8 & $166 / 555$ & 29.9 & $8 / 29$ & 27.6 & \multirow{2}{*}{0.79} \\
\hline No & $410 / 584$ & 70.2 & $389 / 555$ & 70.1 & $21 / 29$ & 72.4 & \\
\hline \multicolumn{8}{|l|}{ Parametrial invasion } \\
\hline Yes & $24 / 566$ & 4.2 & $21 / 538$ & 3.9 & $3 / 28$ & 10.7 & \multirow{2}{*}{0.08} \\
\hline No & $542 / 566$ & 95.8 & $517 / 538$ & 96.1 & $25 / 28$ & 89.3 & \\
\hline \multicolumn{8}{|l|}{ Vaginal invasion } \\
\hline Yes & $24 / 552$ & 4.3 & $21 / 524$ & 4.0 & $3 / 28$ & 10.7 & \multirow{2}{*}{0.09} \\
\hline No & $528 / 552$ & 95.7 & $503 / 524$ & 96.0 & $25 / 28$ & 89.3 & \\
\hline \multicolumn{8}{|l|}{ Positive margin } \\
\hline Yes & $28 / 564$ & 5.0 & $24 / 536$ & 4.5 & $4 / 28$ & 14.3 & \multirow{2}{*}{0.02} \\
\hline No & $536 / 564$ & 95.0 & $512 / 536$ & 95.5 & $24 / 28$ & 85.7 & \\
\hline
\end{tabular}


Table 6. Multivariate analysis of predictive factors of having at least one SLN in atypical area per side

\begin{tabular}{|c|c|c|c|}
\hline Variable & ORa & IC $95 \%$ & p \\
\hline \multicolumn{4}{|l|}{ BMI $\left[\mathrm{kg} / \mathrm{m}^{2}\right]$} \\
\hline$\leq 25$ & 1 & & \\
\hline$>25$ & 0.21 & $0.04-1.06$ & 0.06 \\
\hline \multicolumn{4}{|l|}{ Parity } \\
\hline 0 & 1 & & \\
\hline$\geq 1$ & 0.17 & $0.07-0.39$ & $<0.0001$ \\
\hline \multicolumn{4}{|l|}{ Type of surgical approach } \\
\hline Minimal Invasive Surgery & 1 & & \\
\hline Laparotomy & 0.41 & $0.02-7.22$ & 0.54 \\
\hline \multicolumn{4}{|l|}{ Tumor size } \\
\hline$<20 \mathrm{~mm}$ & 1 & & \\
\hline$\geq 20 \mathrm{~mm}$ & 2.52 & $1.04-6.10$ & 0.04 \\
\hline \multicolumn{4}{|l|}{ Parametrial invasion } \\
\hline No & 1 & & \\
\hline Yes & 3.07 & $0.49-19.07$ & 0.23 \\
\hline \multicolumn{4}{|l|}{ Vaginal invasion } \\
\hline No & 1 & & \\
\hline Yes & 1.51 & $0.22-10.27$ & 0.67 \\
\hline
\end{tabular}

